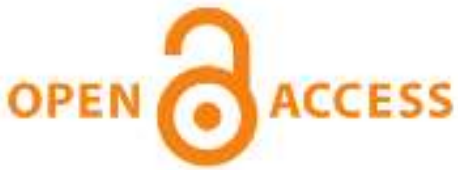 \\ International Journal of Applied Sciences and Biotechnology
}

\author{
A Rapid Publishing Journal
}

ISSN 2091-2609

\section{Indexing and Abstracting}

CrossRef, Google Scholar, Global Impact Factor, Genamics, Index Copernicus, Directory of Open Access Journals, WorldCat, Electronic Journals Library (EZB), Universitätsbibliothek Leipzig, Hamburg University, UTS (University of Technology, Sydney): Library, International Society of Universal Research in Sciences (EyeSource), Journal Seeker, WZB, Socolar, BioRes, Indian Science, Jadoun Science, JourInformatics, Journal Directory, JournalTOCs, Academic Journals Database, Journal Quality Evaluation Report, PDOAJ, Science Central, Journal Impact Factor, NewJour, Open Science Directory, Directory of Research Journals Indexing, Open Access Library, International Impact Factor Services, SciSeek, Cabell's Directories, Scientific Indexing Services, CiteFactor, UniSA Library, InfoBase Index, Infomine, Getinfo, Open Academic Journals Index, HINARI, etc.

\section{CODEN (Chemical Abstract Services, USA): IJASKD}

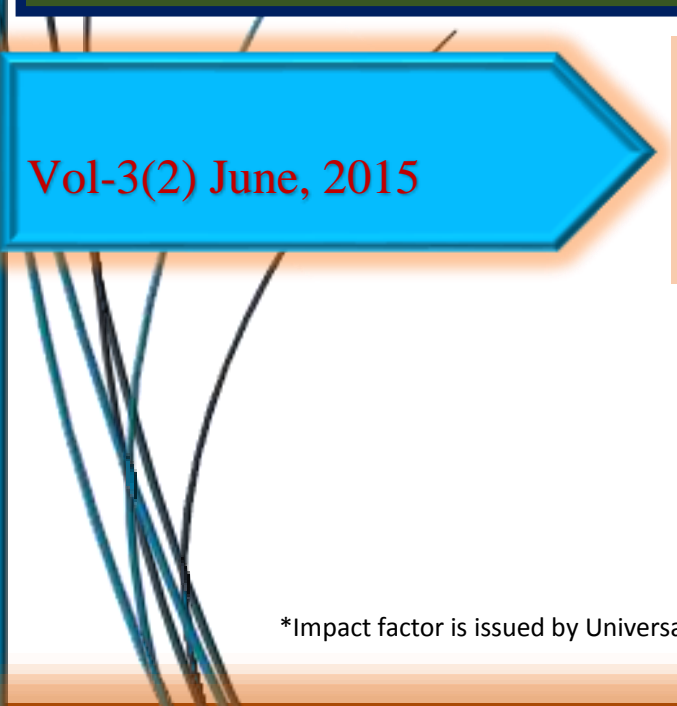

Available online at:

http://www.ijasbt.org

$\&$

http://www.nepjol.info/index.php/IJASBT/index

Impact factor*: $\mathbf{1 . 4 2 2}$

Scientific Journal Impact factor ${ }^{\#:}$ 3.419

SEM-Biotech

Publishing

Index Copernicus Value: $\mathbf{6 . 0 2}$ 


\title{
PROTEIN PROFILE STUDY OF SOME NIGERIAN SESAME (SESAMUM INDICUM L.) ACCESSIONS
}

\author{
*Gbenga Olorunshola Alege \\ Biological Sciences Department, Kogi State University, Anyigba, Nigeria \\ *Email: gbemilege7@yahoo.com
}

\begin{abstract}
This study was carried out to investigate the genetic diversity among 23 sesame (Sesamum indicum L.) accessions obtained from different agro-ecological localities from 10 different states across 4 geopolitical zones in Nigeria using evidence from Sodium Dodecyl Polyacrylamide Gel Electrophoresis (SDS-PAGE). Total seed protein of the studied plants resolved on 12\% SDS-PAGE showed variations in numbers and intensity of bands among the different sesame accessions. Thirteen (13) major bands were recorded in this study. Lack of unique band and presence of common band (band 7) among the 23 studied sesame accessions indicate some levels of genetic affinity and evidence of common evolutionary origin of the sesame genotypes. This band can therefore be tagged as species specific band for discriminating Sesamum indicum. Cluster analysis grouped the 23 sesame genotypes into two clusters with similarity coefficient ranging from 0.42 to 0.96 which indicates existence of genetic diversity; therefore there is ample opportunity for improving the 23 sesame genotypes. Variations in protein bands observed among the 23 studied plants could be attributed to genomic changes taken place during species diversification. It can be concluded that genetic diversity existed among Nigerian sesame for the improvement of characters of interest. Accessions 9 (YOL), 15(OTT), 22 (OFF) and 23 (JAL) are therefore recommended for used in future breeding programs for the development of improved sesame varieties.
\end{abstract}

Keywords: Genetic diversity; accessions; Agro-ecologies; SDS-PAGE; Sesamum indicum,

\section{Introduction}

Sesame (Sesamum indicum L.) is an important annual oilseed crop in the tropics and warm tropics (International Plant Genetic Resources Institute, 2004; Zhigila et al., 2015). Nigeria according to Makinde and Akinoso (2014) is one of the major producers of sesame in Africa and it is grown predominantly in Benue, Nasarawa and Jigawa States. Cultivationof sesame in Nigeria as at year 2003 covers area of 334,685 hectares with annual production of 55 milliontons (Raw Materials Research and Development Council, 2004). As reported by Oduntan et al. (2014) Nigeria is the fifth largest producer of sesame in the world with an estimated production of 120 million tons annually as at 2013. However, this production in 2013 in Nigeria is still low compared to the world's average annual production of 389 million tons. Sesame is commonly called Beniseed in Nigeria while the Hausas, Ibos and Yorubas which are the major tribes in Nigeria call it "Ridi", "Ekuku" and "Isasa", respectively. Other tribes in Nigeria also have different names for the plant. According to Falusi and Salako (2001), the local names given to sesame in Tiv, Igbira and Jukun are "Ishwa", Igorigo" and "Doo" respectively.
The use of molecular markers for assessing genetic diversity has received a great deal of attention in recent years (Woldesenbet et al., 2015). Bharathi et al. (2014) and Sarwar et al. (2015) stated that the study of genetic diversity in crops is essential for high productivity and crop improvement. Traditional sesame landraces as well as related wild species are important source of genetic diversity for breeders and therefore form the backbone of agricultural production (Odongo et al. 2015; Sharma et al., 2014). Akbar et al. (2012) and Sadia et al. (2009) reported that SDS-PAGE is considered to be a dependable method for evaluating genetic diversity in plants because seed storage proteins are independent of environmental fluctuations.

The National Cereals Research Institute (NCRI), Badeggi, Nigeria has the national mandate to conserve and improve sesame in Nigeria (Azeez et al., 2014). The combined efforts of Falusi and Salako (2001) to assemble Nigerian sesame germplasm for conservation and genetic improvement revealed presence of more sesame land racesin Benue and Kaduna states. This according to them was closely followed by Nasarawa and Niger states. Despite this conservation effort in Nigeria in 2001, sesame 
production in comparison with other oil crops is still considered to be below expectation. The development of improved plant cultivars in the opinion of Bharathi et al. (2014) is restricted mainly due to narrow genetic pool.

Nigerian sesame germplasm has ample genetic diversity (Alege and Mustapha, 2013). So far this important natural asset has not been adequately evaluated for the development of high quality sesame varieties in Nigeria. Akbar et al. (2012) and Oduntan et al. (2014) reported that in spite sesame being the first oil seed crop known to man and its numerous uses reported by Makinde and Akinoso (2014), sesame is still a neglected crop. Sharma et al. (2014) reported that presently sesame could not compete with other oil seed crops such as soybeans, sunflower and peanut because of lack of improved varieties. Azeez et al. (2014) and Zhigila, et al. (2015) reported that breeding efforts in Nigeria has concentrated majorly on characterization and cataloguing of germplasm collections using morphoagronomic traits. Alege et al. (2013) therefore recommended the use of protein electrophoresis for the discrimination of Nigerian sesame to complement their findings on morphological studies of Nigerian sesame.

To the best of my knowledge, there is information dearth on the assessment of genetic diversity in Nigerian sesame using SDS-PAGE protein electrophoresis. Against this background, this present study was carried out to investigate the genetic diversity among 23 sesame accessions obtained from different agro-ecological localities in Nigeria using protein profile study.

\section{Materials and Methods}

\section{Seed Source and Planting}

Seeds of 23 accessions of sesame, comprising eighteen traditional and five improved accessions were obtained from 10 states in the North-West, North-East, North-Central and South-West regions of Nigeria between September to November, 2010 during harvesting season. The seeds were packed and sealed in paper envelops and labeled appropriately. A brief description of each sesame accession is shown in Table 1. Seeds of each accession were broadcast in a separate $5 \mathrm{~L}$ plastic bucket that was perforated at the lower end andthen filled with sandy loam soil. The set-up was then placed in the screen house and watered regularly. When seedlings were fully established, two seedlings of each sesame genotype were transplanted into a $5 \mathrm{~L}$ plastic bucket and replicated five times. The Completely Randomized Design (CRD) was adopted for this study. Seedlings were later thinned to one seedling per bucket two weeks after transplanting. Seeds of each accession were composited after harvest and stored for 6 months before processing for protein profile study.

Table 1: Brief Description of the 23 Sesame Accessions Considered for the Study.

\begin{tabular}{lllll}
\hline $\begin{array}{l}\text { Accession } \\
\text { Number }\end{array}$ & Accession Name & Sample sources (State) & Geopolitical Zones & Seed coat colour \\
\hline 1. & O3M & Badeggi (Niger) & North Central & Light brown \\
2. & E8 & Badeggi (Niger) & North Central & Light brown \\
3. & O1M & Badeggi (Niger) & North Central & Light brown \\
4. & O2M & Badeggi (Niger) & North Central & Light brown \\
5. & EXSUDAN & Badeggi (Niger) & North Central & Light brown \\
6. & IBA1 & Ibadan (Oyo) & South West & Dark brown \\
7. & IBA2 & Ibadan (Oyo) & South West & Light brown \\
8. & OKE1 & Okene (Kogi) & North Central & Light brown \\
9. & YOL & Yola (Adamawa) & North East & Light brown \\
10. & MAI & Maiduguri (Borno) & North East & White \\
11. & KAN3 & Kano (Kano) & North West & Light brown \\
12. & KAN2 & Kano (Kano) & North West & Light brown \\
13. & KAN1 & Kano (Kano) & North West & Light brown \\
14. & MAK & Makurdi(Benue) & North Central & Light brown \\
15. & OTT & Otukpo (Benue) & North Central & Dark brown \\
16. & ZAR & Zaria (Kaduna) & North Central & Dight brown \\
17. & ANY1 & Anyigba (Kogi) & North Central & Dark brown \\
18. & ANY2 & Anyigba (Kogi) & North Central & Black \\
19. & OKE2 & Anyigba (Kogi) & North Central & Black \\
20. & ILO1 & Ilorin (Kwara) & North Central & Nlack \\
21. & ILO2 & Ilorin (Kwara) & North Central & North Central \\
23. & OFF & Offa (Kwara) & North East & \\
\hline & JAL & & & brown \\
\hline
\end{tabular}




\section{Protein Finger Printing Using SDS Gel Electrophoresis of Seed Proteins}

Seeds from each sesame sample were dried in an oven before homogenizing with an extraction buffer containing $0.05 \mathrm{M}$ Tris- $\mathrm{HCl}$ ( $\mathrm{pH} 7.4) 4^{\circ} \mathrm{C}$. Bromophenol blue was added to the sample buffer as a tracking dye to watch the movement of proteins in the gel. The homogenate was centrifuged at 10,000 r.p.m for 15 minutes at $4^{\circ} \mathrm{C}$ and the supernatant was used for electrophoresis. $12 \%$ SDS-gel was used for the run following the Discontinuous Electrophoretic method of Leammli (1970). The Sigma ${ }^{(\mathrm{R})}$ Maker used to trace the bands contains 13 proteins ranging from 6,500 to $205,000 \mathrm{kbs}$.

\section{Data Analysis}

To avoid ambiguity in the data, only clear and consistent protein bands between 6,500 and 205,000 kbs were considered for data recording. Bands clearly visible in at least one genotype were scored (1) for present, 0 for absent and entered into a data matrix. Similarity Matrix (coefficient) proposed by Nei and Li (1979) was used to calculate the degree of similarity $\left(\mathrm{S}_{\mathrm{ab}}\right)$, between two cultivars $\mathrm{a}$ and $\mathrm{b}$ according to the formula:

$\mathrm{S}_{\mathrm{ab}}=2 \mathrm{~N}_{\mathrm{ab}} /\left(\mathrm{N}_{\mathrm{a}}+\mathrm{N}_{\mathrm{b}}\right)$

Where $\mathrm{N}_{\mathrm{ab}}=$ number of bands common to both species $\mathrm{a}$ and $b ; N_{a}=$ number of bands in species $a ; N_{b=}$ number of bands in species $b$.

Hierarchical clustering (dendogram) was constructed using Unweighted Pair Group Method with arithmetic Average (UPGMA) with SPSS v16 window software.

\section{Result and Discussion}

Electrophoregram of the protein profile shown in Plate1a-c revealed that the 23 sesame accessions have different band patterns. Thirteen (13) major bands were recorded while marked differences were recorded for numbers, combination and intensity of bands among the different accessions. This strongly indicates that each of the 23 studied sesame samples is a distinct genotypes and protein electrophoresis is a useful tool for their discrimination. Dudwadkar et al. (2015) reported that the diversity in protein profiles and seed storage proteins have potential for species delimitation and also serves as marker for intra- and inter- specific hybridization. Electrophoresis of proteins is a powerful tool for identification of genetic diversity because proteins stored in the seeds are highly independent of environmental fluctuations (Alege et al., 2014; Eshsanpour et al., 2010).

From the result of bands present or absent in the 23 Sesame (Sesamum indicum) studied in Table 2, twelve of the twenty three sesame genotypes lacked band 1 while sixteen accessions lacked band 2. Seven sesame genotypes lack bands 3 while four accessions each lacked bands 5, 6 and 10 .
Bands 4,8 and 9 were lacking in three sesame genotypes while bands 11, 12 and 13 were lacking in three, four and six accessions respectively. It can also be deduced from the same table that $02 \mathrm{M}$ had the highest number of bands (13) while the least number of bands (6) was observed in OFF. Band number 7 is the only common band among the studied plants whereas no band is unique to any of the 23 sesame accessions. The differences observed in banding patterns among the studied plants depict genetic divergence among the studied sesame species over evolutionary time which could be used for their improvement. Sadia et al. (2009) found out that landraces are useful source of genetic variation and the greater the level of variation, the greater the chance of a landrace possessing gene combinations of interest to plant breeders. Lack of unique band (band peculiar to an accession) among the studied sesame accessions indicates common gene expression while the presence of band 7 in all the 23 sesame accessions strongly suggests that the gene coding for the protein band has been fixed in Nigerian sesame. This therefore suggests common phylogeny and ancestry among the studied plants. This finding is further strengthened by the earlier report of Alege et al. (2014) on members of the Fabaceae family. Akinwusi and Illoh (1995) also opined that when a band appears in every individual in a population, it is assumed that the gene which codes the enzyme or protein does not vary. Along the same line, bands 4,8 and 9 are almost fixed in Nigerian sesame because IBA (6), ILO (21) and JAL I (23) were the only sesame samples respectively lacking them. This is an indication that these 3 bands are adaptive genes which have evolved, became dispersed and almost completely fixed in Nigerian sesame. Electrophoregrams Showing Protein Banding Patterns for the 23 Sesame Genotypes is shown in Fig. 1 (a-c).

Table 3 showed that the highest similarity coefficient of 0.96 was observed between 7 (IBA2) and 1 (03M), 4 (02M), 18 (ANY2) and 19 (OKE2). Similarity index of 0.96 was also recorded between 21 (ILO2) and 4 (02M), 8 (OKE1) and 10 (MAI). Similarly, 0.96 similarity index was also recorded between 14 (02M) and 9 (YOL), 18 (ANY2) while the least similarity coefficient of 0.47 was observed between 9 (YOL) and 22 (OFF). The similarity coefficient range of 0.42 to 0.96 observed in this study is consistent with the 0.40 to 0.92 reported by Tabatabaei et al. (2011) on Iranian and exotic sesame. This further indicates the existence of genetic diversity among the studied sesame. Therefore there are ample opportunities for improving the 23 sesame genotypes for characters of interest. A cross between accessions 9 (YOL) and 22 (OFF) been the least similar accessions among the 23 studied sesame will be a right step in the right direction towards improvement in Nigeria sesame. 
Cluster analysis result put the 23 sesame genotypes into two major clusters (Fig 2). The $1^{\text {st }}$ cluster (A) comprised of 22 accessions while only accession 15 (OTT) occupied the $2^{\text {nd }}$ cluster (B). In cluster A, the first sub-cluster (A1) consists of 20 sesame accession while the $2^{\text {nd }}$ sub-cluster (A2) comprised of 2 accessions (i.e ILO1 and JAL). This reveals low genetic diversity as most (22) of the 23 studied sesame accessions occupied a single cluster. The existence of low genetic diversity in the opinion of Peddakasim et al. (2015) could be attributed to genotype homogeneity or purity. The existence of genetic diversity can therefore be used to maximize the expression of heterosis among the studied sesame. Some of the sesame accessions evaluated using electrophoresis appeared to be linked with their geographical origin and those genotypes from similar geographical location were found to have close genetic association in some cases as observed between accessions 3 $(01 \mathrm{M})$ and $4(02 \mathrm{M})$ both from Niger state as well as, 17 (ANY1) and 18 (ANY2) from Anyigba in Kogi state and 11
(KAN1) and 12 (KAN2) from Kano state. This clustering pattern is consistent with the earlier report of Alege and Mustapha (2013) on morphological attributes in Nigerian sesame. This finding strongly supports their earlier report that common gene control exists between these sesame accessions and therefore could be regarded as ecotypes. The disparities observed between the findings in this study and those reported by Alege and Mustapha (2013) on morphological attributes strongly supported the report of Yatung et al. (2014) that discrepancy could exist between morphological traits and protein profile due to the impact of environment on the former. The close relationship between sesame accessions from different geographical origins in Nigeria could be attributed to exchange of sesame varieties between farmers across different regions. This finding agrees with the report of Tabatabaei et al. (2011) that human factor is a very important factor that accounted for association between accessions from different regions.

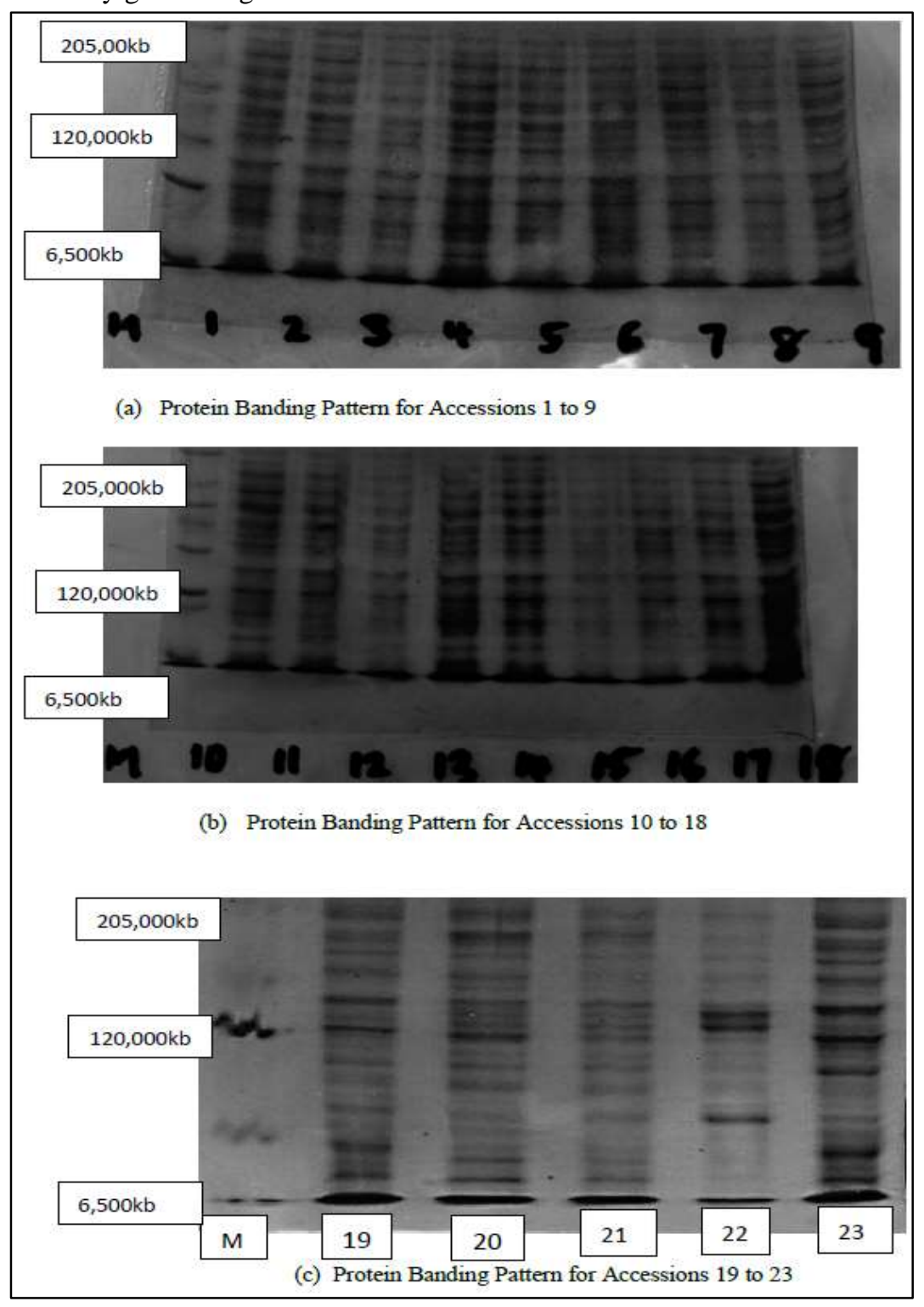

Fig 1(a-c): Electrophoregrams Showing Protein Banding Patterns for the 23 Sesame Genotypes. 
In this study, there is no basis to discriminate Nigerian sesame base on seed coat colour since sesame seeds with different coat colours clustered together. Sesame with black seed coat show heterogeneous clustering on the dendrogram which further strengthened the fact that selection on the basis of seed coat colour for hybridization may not be effective in sesame improvement program. Among all the 23 sesame accession studied, accessions 9 (YOL), 15(OTT), 22 (OFF) and 23 (JAL) are highly diversified from each other. Hence these accessions are recommended for future breeding programs for the development of improved sesame varieties

\section{Conclusion and Recommendation}

On the basis of the results obtained in this study, it can be concluded that genetic diversity existed among Nigerian sesame; this therefore gives ample opportunities for improving the 23 studied sesame genotypes for characters of interest. Specifically, accessions 9 (YOL), 15(OTT), 22 (OFF) and 23 (JAL) are recommended for used in future breeding programs for the development of improved sesame varieties while the less divergent accessions in this study may be preserved as gene bank for future sesame improvement in Nigeria. Furthermore, other molecular techniques like Random Amplified Polymorphic DNA (RAPD) and Fragment Length Polymorphic DNA (FLPD) should be used to discriminate the studied crop to compliment the findings of this study.

\section{Dendrogram using Average Linkage (Between Groups)}

\section{Rescaled Distance Cluster Combine}

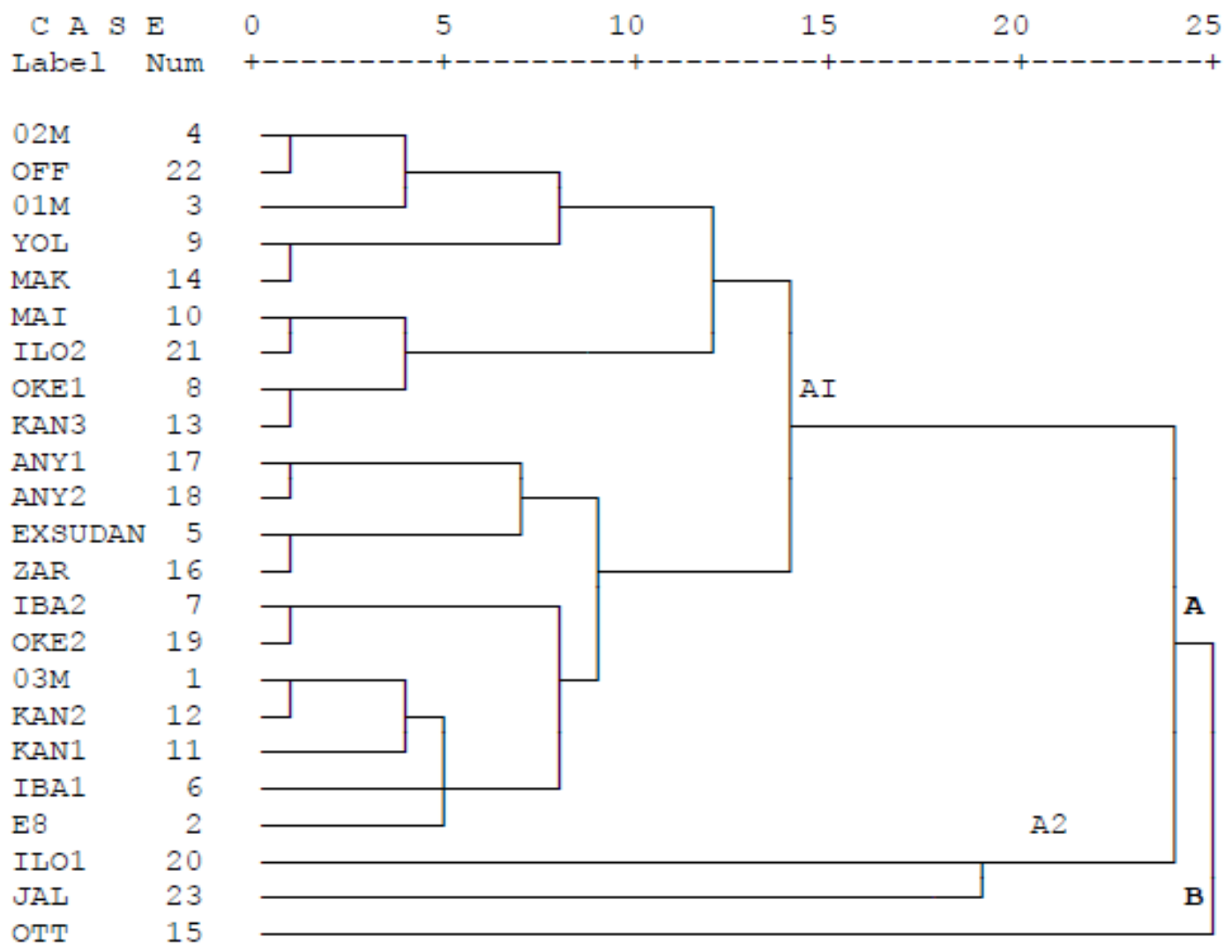

Fig 2: Dendrogram of Protein Profile for the 23 Sesame Accessions Studied. 
G.O. Alege (2015) Int J Appl Sci Biotechnol, Vol 3(2): 322-329

Table 2: Bands Present or Absentin the 23 Sesame (Sesamum indicum) studied.

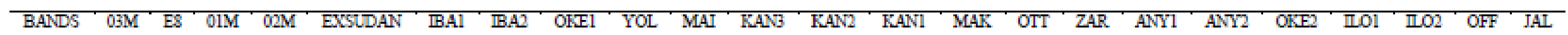

\begin{tabular}{|c|c|c|c|c|c|c|c|c|c|c|c|c|c|c|c|c|c|c|c|c|c|c|c|}
\hline 1 & - & - & - & + & $\cdot$ & - & + & + & + & + & - & - & + & + & - & - & - & + & + & - & + & - & + \\
\hline 2 & - & - & + & + & - & - & - & - & + & + & - & - & - & + & - & - & - & - & - & - & + & - & - \\
\hline 3 & + & + & + & + & + & + & + & - & + & - & + & $\cdot$ & - & + & + & + & + & + & + & - & - & - & + \\
\hline 5 & + & + & + & + & + & + & + & + & + & + & + & + & + & + & + & + & + & + & - & - & + & - & - \\
\hline 6 & + & + & + & + & + & + & + & + & + & + & - & + & + & + & + & + & + & + & + & - & + & + & - \\
\hline 9 & + & + & + & + & + & + & + & + & + & + & + & + & + & + & + & + & + & + & + & + & + & + & - \\
\hline 10 & + & + & + & + & - & + & + & + & + & + & + & + & + & + & - & + & + & + & + & - & + & - & + \\
\hline 11 & + & + & + & + & + & + & + & + & + & + & + & + & + & + & - & - & + & + & + & + & + & - & + \\
\hline 12 & + & - & + & + & + & + & + & + & - & - & + & + & $\cdot$ & + & + & + & + & + & + & + & + & + & + \\
\hline
\end{tabular}

+ , Band present; -, Band absent 
Table 3: Similarity Index for Protein profile Among the 23 Sesame Genotype Studied.

\begin{tabular}{|c|c|c|c|c|c|c|c|c|c|c|c|c|c|c|c|c|c|c|c|c|c|c|c|}
\hline & $03 \mathrm{M}$ & E8 & $01 \mathrm{M}$ & $02 \mathrm{M}$ & $\begin{array}{l}\text { EXSU } \\
\text { DAN }\end{array}$ & IBA1 & IBA2 & OKE1 & YOL & MAI & KAN3 & KAN2 & KAN1 & MAK & OTT & ZAR & ANY1 & ANY2 & OKE2 & ILO1 & ILO2 & OFF & JAL \\
\hline $03 \mathrm{M}$ & - & & & & & & & & & & & & & & & & & & & & & & \\
\hline E8 & 0.95 & - & & & & & & & & & & & & & & & & & & & & & \\
\hline $01 \mathrm{M}$ & 0.86 & 0.91 & - & & & & & & & & & & & & & & & & & & & & \\
\hline $02 \mathrm{M}$ & 0.91 & 0.87 & 0.96 & - & & & & & & & & & & & & & & & & & & & \\
\hline EXSUDAN & 0.95 & 0.90 & 0.87 & 0.87 & - & & & & & & & & & & & & & & & & & & \\
\hline IBA1 & 0.95 & 0.90 & 0.87 & 0.87 & 0.90 & - & & & & & & & & & & & & & & & & & \\
\hline IBA2 & 0.96 & 0.91 & 0.92 & 0.96 & 0.90 & 0.91 & - & & & & & & & & & & & & & & & & \\
\hline OKE1 & 0.91 & 0.82 & 0.83 & 0.92 & 0.90 & 0.86 & 0.96 & - & & & & & & & & & & & & & & & \\
\hline YOL & 0.82 & 0.86 & 0.87 & 0.92 & 0.76 & 0.76 & 0.87 & 0.82 & - & & & & & & & & & & & & & & \\
\hline MAI & 0.82 & 0.86 & 0.87 & 0.92 & 0.76 & 0.76 & 0.87 & 0.91 & 0.91 & - & & & & & & & & & & & & & \\
\hline KAN3 & 0.95 & 0.90 & 0.91 & 0.86 & 0.90 & 0.90 & 0.91 & 0.86 & 0.76 & 0.76 & - & & & & & & & & & & & & \\
\hline KAN2 & 0.95 & 0.90 & 0.91 & 0.86 & 0.90 & 0.90 & 0.91 & 0.95 & 0.76 & 0.86 & 0.80 & - & & & & & & & & & & & \\
\hline KAN1 & 0.86 & 0.90 & 0.78 & 0.86 & 0.80 & 0.80 & 0.82 & 0.95 & 0.86 & 0.95 & 0.80 & 0.90 & - & & & & & & & & & & \\
\hline MAK & 0.78 & 0.82 & 0.92 & 0.96 & 0.82 & 0.78 & 0.92 & 0.87 & 0.96 & 0.87 & 0.82 & 0.82 & 0.82 & - & & & & & & & & & \\
\hline OTT & 0.78 & 0.71 & 0.74 & 0.70 & 0.71 & 0.71 & 0.74 & 0.67 & 0.78 & 0.56 & 0.82 & 0.71 & 0.59 & 0.73 & - & & & & & & & & \\
\hline ZAR & 0.90 & 0.84 & 0.86 & 0.82 & 0.84 & 0.84 & 0.86 & 0.80 & 0.80 & 0.70 & 0.84 & 0.84 & 0.74 & 0.86 & 0.88 & - & & & & & & & \\
\hline ANY1 & 0.95 & 0.90 & 0.91 & 0.86 & 0.90 & 0.90 & 0.82 & 0.86 & 0.86 & 0.76 & 0.90 & 0.90 & 0.80 & 0.91 & 0.82 & 0.95 & - & & & & & & \\
\hline ANY2 & 0.91 & 0.86 & 0.87 & 0.92 & 0.86 & 0.95 & 0.96 & 0.91 & 0.91 & 0.82 & 0.86 & 0.86 & 0.86 & 0.96 & 0.78 & 0.90 & 0.95 & - & & & & & \\
\hline OKE2 & 0.91 & 0.86 & 0.87 & 0.92 & 0.86 & 0.86 & 0.96 & 0.91 & 0.82 & 0.82 & 0.86 & 0.86 & 0.86 & 0.87 & 0.67 & 0.80 & 0.86 & 0.91 & - & & & & \\
\hline ILO1 & 0.78 & 0.71 & 0.74 & 0.70 & 0.82 & 0.71 & 0.74 & 0.78 & 0.56 & 0.67 & 0.82 & 0.82 & 0.71 & 0.63 & 0.71 & 0.63 & 0.71 & 0.67 & 0.78 & - & & & \\
\hline ILO2 & 0.87 & 0.82 & 0.92 & 0.96 & 0.82 & 0.82 & 0.92 & 0.96 & 0.87 & 0.96 & 0.82 & 0.91 & 0.91 & 0.92 & 0.63 & 0.76 & 0.82 & 0.87 & 0.87 & 0.74 & - & & \\
\hline OFF & 0.70 & 0.50 & 0.67 & 0.63 & 0.75 & 0.63 & 0.67 & 0.71 & 0.47 & 0.59 & 0.63 & 0.75 & 0.63 & 0.56 & 0.62 & 0.67 & 0.63 & 0.59 & 0.71 & 0.77 & 0.67 & - & \\
\hline JAL & 0.80 & 0.94 & 0.76 & 0.82 & 0.73 & 0.74 & 0.86 & 0.80 & 0.90 & 0.70 & 0.84 & 0.74 & 0.74 & 0.76 & 0.63 & 0.67 & 0.74 & 0.80 & 0.90 & 0.75 & 0.76 & 0.53 & - \\
\hline
\end{tabular}




\section{References}

Akbar F, Yousaf N, Rabbani AM, Shinwari ZK and Masood SM (2012) Study of Total Seed Proteins Pattern of sesame (Sesamum indicum L.) Landraces via Sodium Dodecyl Sulfate Polyacrylamide Gel Electrophoresis (SDSPAGE).Pak. J. Bot. 44(6): 2009-2014.

Akinwusi O and Illoh HC (1995) Crude Protein Electrophoresis of Seeds of Some species of Hibiscus. Nigerian Journal of Botany. 8:71 - 76 .

Alege GO, Abu NE and Sunday CE (2014) Seed Protein Electrophoresis of Some Members of the Family Fabaceae. African Journal of Biotechnology 13(36): 3730-3735.

Alege GO and Mustapha OT (2013) Assessment of Genetic Diversity in Nigerian Sesame (Sesamum indicum L.) Using Morphological Markers, Proceedings of Genetic Society of Nigeria (GSN) $20^{\text {th }}-24^{\text {th }}$ October, 2013, Federal University, Lafia, Nasarawa State.78-88 Pp.

Alege GO, Mustapha OT, Ojo S and Awosemo BM (2013) TheMorphological, Proximate and Mineral Responses of Sesame to Different Nutrient Sources. Global Journalof Biosciences and Biotechnology 2(1): 12-16.

Azeez MA, Aremu CO and Olaniyan OO (2013) Assessment of Genetic Variation in Accessions of Sesame (Sesamum indicum L.) and its Crosses by Seed Protein Electrophoresis. Journal of Agroalimentary Processes and Technologies 19(4): 383-391.

Bharathi D, Rao TV, MohanYC, Bhadru D and Venkanna V (2014) Genetic Variability Studies in Sesame (Sesamum indicum L.).International Journal of Applied Biology and Pharmaceutical Technology 5(4): 31-33.

Dudwadkar S, Parab M and Singh S (2015) Diversity Analysis Among Few CucurbitaceaeUsing Seed Protein Profile, International Journal of Plant, Animal and Environmental Sciences 5(1): 146-151.

Ehsanpour AA,Shojaie B and Rostami F (2010) Characterization of Seed Storage Protein Patterns of Four Iranian PislachiosUsing SDS-PAGE.Natural Sciences. 2 (7): 737740.

Falusi AO and Salako EA (2001) Assemblage of Sesame Germplasm for Conservation and Genetic Improvement in Nigeria. Plant Genet. Resources Newsletter. 12:25 - 38.

IPGRI (2004) Descriptors for Sesame (Sesamumspp).International Plant Genetic Resources Institute, Rome, Italy, 64Pp.

Leammli UK (1970). Cleavage of Structural Proteins During the Assembly of the Head of Bacteriophage T4. .Nature 22:680-685.

Makinde FM and Akinoso R (2014) Comparision between the Nutritional Quality of Flour Obtained from Raw, Roasted and Fermented Sesame (Sesamum indicum L.)Seed Grown in Nigeria. Acta Sci. Pol., Technol. Aliment. 13(3): 309319.
Nei N and Lei W (1979) Mathematical Model for Studying Genetic Variation in terms of Restriction Endonucleases. Proc. Natl. Acad. Sci. 76: 5269-5273.

Oduntan AO, Olaleye O, Akinwande BA and Fasoyiro SB (2014) Effect of Plant Maturity on the Anti-nutrient of Sesamum radiatum Leaves. Global Journal of Scientific Researches 2(1): 7-11.

Odongo FO, Oyoo ME, Wasike V, Owuoche JO, Karanja L and Korir P (2015) Genetic Diversity of Bambara Groundnut (Vigna subterranea (L.) Verdc.)L and races in Kenya Using Microsatellite Markers. African Journal of Biotechnology 14(4): 283-291.

Peddakasim D, SuneethaP, Lakshmi SU, Srideepthi R and Krishna MSR(2015) Seed Storage Protein Profiling and Phylogenetic Relationships of Capsicum annun L. Cultivars Using SDS-PAGE, Research Journal of Biotechnology 10(2): 1-4.

Raw Materials Research and Development Council (RMRDC) (2004) Survey Report of Ten Selected Agro-raw Materials in Nigeria.Raw Materials Research and Development Council, Abuja, Nigeria, 89Pp.

Sadia M, Malik SA, Rabbani MA and Pearce SR (2009) Electrophoretic Characterization and Relationships between Some Brassica species. Electronic Journal of Biology 5 (1): 1-4.

Sarwar G, Hossain MS, Rashid MH and Parveen S (2015) Assessment of Genetic Variability for Agromorphological Important Traits in Aman Rice (Oryza sativa L.). .International Journal of Applied Sciences and Biotechnology 3(1): 73-79.

Sharma E, Shah IS and Khan F (2014) A Review Enlightening Genetic Divergence in Sesamum indicumBased on Morphological and Molecular Studies. International Journal of Agriculture and Crop Sciences 7(1): 1-9.

Tabatabaei I, Pazouki L, Bihamta RM, Mansoori S, Javaran MJ and Niinemets U (2011) Genetic Variation among Iranian Sesame (Sesamum indicumL.) Accessions vis-à-vis Exotic Genotypes on the Basis of Morpho-physiological Traits and RAPD Markers. Australian Journal of Crop Science 5(11): 1396-1407.

Woldesenbet DT, Tesfaye K and Bekele E (2015) Genetic Diversity of Sesame Germplasm Collection (Seamumindicum L.): Implication for Conservation, Improvement and Use.International Journal for biotechnology and molecular Biology Research 6(2): 718.

Yatung T, Dubey RK., Singh V, Upadhyay G and Singh S (2014) Studies on Seed Protein Profiling of Chili (Capsicum annum L.)Genotypes of North India. Austr. J. Crop Sci. 8(3): 369-377.

Zhigila DA, SawaFBJ and Abdul SD (2015) Morphometric Study of Accessions of Sesamum indicum L. Collected from Nigeria. African Journal of Plant Science 9 (2): 56-64. 